\title{
AN ANALYSIS OF FIGURATIVE LANGUAGE USED IN THE LYRIC OF "A WHOLE NEW WORLD" BY ZAYN MALIK AND ZHAVIA WARD
}

\author{
Siti Nursolihat ${ }^{1}$, Evie Kareviati ${ }^{2}$ \\ ${ }^{1}$ IKIP Siliwangi \\ ${ }^{2}$ IKIP Siliwangi \\ ${ }^{1}$ sitinursolihat@student.ikipsiliwangi.ac.id, ${ }^{2}$ ekareviati@gmail.com
}

\begin{abstract}
Language is a tool of communication used by people anywhere and every time. Now days people commonly find a figurative language in daily life, for example in a lyric of song. Figurative language is a way to express an idea in implicit way. This research is trying to analyze the figurative languages which exist in the lyric of song "A Whole New World" and trying to find out its meaning by analyzing its contextual meaning. This is a descriptive qualitative research. The data instrument is the song lyric which taken from Genius website. The result showed that this song consist of some figurative languages, such as alliteration, simile, personification, metaphor, and hyperbole. Furthermore, the most figurative language used in the lyric is metaphor. It is highly relatable with the imaginative theme of the song itself. The contextual meaning of each figurative language is also explained based on the situation of the lyric.
\end{abstract}

Keywords: Figurative Language, Song Lyric, Contextual Meaning

\section{INTRODUCTION}

Language is a tool of communication used by the people, orally or writing. Basic aim of language learning nowdays is communication and vocabulary plays an important role in conversation (Komorowska, 2005) as cited in Nurdiansyah, Asyid, \& Parmawati (2019). (2019).Taking and giving information, interacting with the people are part of communication. It means language takes highly essential role since in daily life the people interact to each other everywhere and whenever. However talk about language, Sugiono (2013) as cited in (Nurcitrawati, Kareviati, \& Atmawidjaja, 2019) stated that literally it's not enough to understand only the form of language and the pronunciation, because it requires to understand the meaning. For that reason in this modern era people communicate in various way includes talks through literature such as poetry, novel and song lyric which commonly the messages or the real meaning of the words are implicit by using figurative language. According to Harya, (2017) Figurative language is language that uses words or expressions with a meaning that is different from the literal interpretation. So that inferring meaning of the words or expression is needed, because it may not understandable if the words interpreted literally by the meaning in the dictionary.

Song is extremely popular right now since the people generally love to listen to it. According to Apsari (2012), by using songs the students tend to be more active in the teaching and learning process. Beside the rhythm, its lyric also becomes the consideration of the reason why people like a song because lyrics offer a thoughtful understanding about the song's message. Recently song from Zayn Malik and Zhavia Ward entitled A Whole New World is absolutely famous, since it come as a soundtrack of Alladin movie which produced by Disney and released in 2019. 
Many people from around the world listen to it and even cover it. However, it is found that the composer write the lyric in extraordinary way by using some figurative language.

Previously there are some studies that also talks about figurative language in a song. For instance, Padillah et al., (2016) with her journal entitled "Figurative Language Used in One Direction's Album Entitled Up All Night". It was concluded that Up All Night Album which released in 2012 consist of six types of figurative language. Those are repetition, parallelism, personification, metaphor, simile also hyperbole. Beside it, Stiawati \& Maryani (2018) conducted the similar research entitled "An Analysis of Figurative Language in Taylor Swift's Song Lyrics". In the result it was found that there were seven figurative language where hyperbole and simile become the most dominant one.

For that reason the writer is interested to analyze the types of figurative language that used in the song in order to find out the figurative language used and the most take in A Whole New World song's lyric and also to find out its contextual meaning. According to Ulman in Ardhyanti \& Supriyatiningsih, (2020) contextual meaning can be said as the meaning of words that are found in particular situation. So that, contextual meaning is the meaning comes from the certain situation and context which it may has different meaning in other situation. This study is expected to lead people to the better understanding of the song especially A Whole New World. Because it is believed the better people understand the lyric, the more people enjoy the song and the music.

\section{METHOD}

This is a descriptive qualitative research. Qualitative research works with a wide range of data including recorded interviews, various types of texts, documents, and images. Qualitative data analysis usually is done with words Kaswan, Dasep Suprijadi, (2016) This research is designed to discover some figurative language in song A Whole New World and to interpret its meaning. It means this research is only focused on words and meaning, it is not using statistical method in analyzing data.

Descriptive qualitative is a research which tends to use non numerical data and focuses on meaning making. related to that, Sandelowski (2000) as cited in Seixas et al., (2018)said that descriptive qualitative differs from other types of qualitative research, the descriptive rather than interpretive in focus. Since it focuses on the analysis data, usually the result is a comprehensive summarization.

Data is a foundation of a study since data is a collection of information which will be analyzed. The source of data for this research is taken from Genius ("ZAYN \& Zhavia Ward - A Whole New World (End Title) Lyrics | Genius Lyrics," n.d.) the steps of analysis data were identifying the types of figurative language based on the theory, finding out its meaning by analyzing its contextual meaning and finally making conclusion.

\section{RESULTS AND DISCUSSION}

\section{Results}

There are some figurative languages found in the lyric A Whole New World, such as metaphor, simile, hyperbole and alliteration. However in the table below showed that metaphor is the figurative language that frequently comes up in this lyric. The result of the analysis is as follow. 


\begin{tabular}{ccc}
\hline Figurative & Lyric & $\begin{array}{c}\text { Percentage } \\
\text { Language }\end{array}$ \\
\end{tabular}

\begin{tabular}{ccc}
\hline Aliteration & $\bullet \quad \begin{array}{l}\text { shining, shimmering, splendid } \\
\text { Simile }\end{array}$ & $20 \%$ \\
\hline Metaphore & $\bullet \quad$ I'm like a shooting star & $10 \%$ \\
\hline $\begin{array}{l}- \text { A new fantestic point of view } \\
-\quad \text { It's crystal clear }\end{array}$ & $40 \%$ \\
\hline through an endles diamond sky & \\
\hline
\end{tabular}

\begin{tabular}{|c|c|c|}
\hline Personification & - with a new horizon to pursue & $10 \%$ \\
\hline Hyperbole & $\begin{array}{l}\text { - I can show you the world } \\
\text { A hundred thousand things to see }\end{array}$ & $20 \%$ \\
\hline
\end{tabular}

\section{Discussion \\ The contextual meaning of figurative language}

The song entitled A Whole New World is one of legend song from Disney which now we know as Aladin's soundtrack. Actually it is released for the first time in 1992. According to CNN Indonesia (Anonym, 2019) this song is ever got rewards in 1993. It was Oscar Trophy for category the best original song and Grammy Trophy for category song of the year. However A Whole New World song is remade again in 2019 with new rhythm and this new version is sung by Zayn Malik and Zhavia Ward. This song is having imaginative theme which generally talk about how the way Aladin shows the freedom to the princess who always live in a castle. The song illustrate how beautiful the world and the princess fells amazed of what she see. A whole new world as a title of this song means a world that is just seen by the princess. It is a new world for her since she never go out from the castle before. This song contains some figurative languages, such as alliteration, metaphor, simile, personification and hyperbole.

Moreover, metaphor is figurative language that the most repeatedly come up in this song's lyrics, the percentage reaches $40 \%$ meanwhile the others are only $10 \%$ to $20 \%$. As we know that metaphor is kind of analogy figurative language for that reason no wonder if the writer use metaphor for many times since this song is an imaginative song, which is an imagination of a princess and Aladin in a flying carpet. The more detailed explanation about figurative language found in A Whole New World song's lyric is as follow.

\section{Alliteration}


Alliteration is part of figures of sound. (Fitria, 2018) stated that "Alliteration is the repetition of the initial consonant in two or more words". Usually the repetition is in consonant words meanwhile the aim of this figurative language is to convey a particular effect, to create a beautiful sentence, or to emphasize. There are two lines of A Whole New World's lyric which use alliteration. Those are:

- shining shimmering splendid. it is classified as alliteration since the constant sound ' $\mathrm{S}$ ' is being repeated at the beginning of the word. This line is describing the world and how beautiful it is.

- soaring, thumbling, freewheeling. It is also alliteration because the ending 'ing' repeated. This line is describing the up and down of the journey.

\section{Simile}

Simile is generally the comparison of two things essentially unlike, on the basis of a resemblance in one aspect. Simile uses connective word such as word "like" and "as" to compare the similarity (Nurhaida \& Marlina, 2017)This figurative language tries to compare the things by using connective word. This is usually used to vivid and empower the writing. the line which use simile is:

- I'm like a shooting star in the song is classified as simile, because It's comparing herself to a shooting star with the word 'like'. This line means that she can't back to the place where she used to be, before she comes to the new place. It's like a shooting star, once it comes to the earth it cannot go back to the sky.

\section{Metaphor}

Metaphor is also part of figures of similarity. (Setiawati \& Maryani, 2018)stated that "Metaphor is a variety of analogy which compares two things directly" which means this figurative language is actually a bit resembled with simile. But metaphor is direct comparison without using connection word. There are two lines using metaphor in this lyric. Those lines are:

- A whole new world. it is comparing the outside of the castle and the new world. however actually there is no new world. it is called a new world because the princess never see it before since the princess always stay at the castle. The castle is like an old world for her and the outside is a new world.

- A new fantastic point of view. This line is a bit similar to the previous line " a whole new world". This is comparing the outside of castle that just the princess know to the new point of view which is it looks so fantastic for the pricess.

- it's crystal clear. The line is comparing the clear view of world when Aladin was on the carpet with the clear crystal. It tries to say that the world looks so clear and beautiful such a crystal.

- through an endless diamond sky. it is comparing the star to diamond directly as we know that star and the diamond has the similarity which is bright and sparkling. It's mean the sky is full of star and sparkling like a diamond.

\section{Personification}

Personification is the figurative language that apply human characteristics into an abstract quality for example It gives animals or objects ideas as if they can act and perform the actions like human beings, (Fitria, 2018). So personification is trying to illustrate that inhuman can do what human do, which in fact it is impossible. The line of lyric which using personification is: 
- With new horizons to pursue. The lyric shows as if horizon is able to run like human until they should pursue it. Literally the horizon is won't going anywhere, it stay in its place. So that it can be concluded that it is personification, which means there are many things to see in the world.

\section{Hyperbole}

According to Padillah et al., (2016)it is said that "Hyperbole is kind of figurative language that is used to make the object become bigger than real object" It can be concluded that hyperbole is overstatement, exaggeration and sometimes it is not realistic an, and usually it is used for catching reader's intention. There are found four hyperbole in this lyric'

- I can show you the world. in this line, it doesn't mean that the man can show the world in real to the girl. It means he can show many things to her but it stated in extraordinary way to show that the man can do many things for the girl.

- A hundred thousand things to see. The meaning of this line is so many things to see. It can be seen that it show the overstatement. Because in real the things to see is uncountable.

\section{CONCLUSION}

This study analyzed the song which is being famous lately. It was Aladin Soundtrack entitled A Whole New World, a new version one, that is sung by Zayn Malik and ZhaviaWard. Based on the data on the discussion part above, it was found that this song contains some figurative languages namely: alliteration, simile, metaphor, personification and hyperbole. However metaphor is the most used among the other figurative languages. As we know that metaphor is a figurative language of similarity as well as simile. So that it can be concluded that the composer or song writer tried to describe and to show how beautiful the world is by using metaphor figurative language. After all for the better understanding, the contextual meaning is used to identify the meaning of each figurative language of this song. For that reason hopefully the listener will get the better experience for when listening this song.

\section{ACKNOWLEDGMENTS}

The highest gratitude and thanks to Allah SWT for giving us strength, health and motivation in finishing this. This article entitled "An Analysis of Figurative Language In Song A Whole New World By Zayn Malik And Zhavia Ward" which is submitted as a final requirements at English Education Program, in IKIP Siliwangi Bandung.

The writers say a lot of thank to everybody who support us all this time, especially to Ms. Evie Kareviati, M.Pd. who guide us to write this article, and unforgettable to my colleagues who have support us in various ways.

\section{REFERENCES}

Anonym. (2019). 5 “A Whole New World” Yang Iringi "Aladdin” Sepanjang Masa.

Apsari, Y. (2012). Teaching English Vocabulary Through Songs. Universitas Pendidikan Indonesia.

Ardhyanti, S. V., \& Supriyatiningsih, S. (2020). Figurative Language Analysis In Celine Dion's Song Lyrics Falling Into You Album. Project (Professional Journal Of English Education), 3(1), 11.

Fitria, T. N. (2018). Figurative Language Used In One Direction's Album Entitled Up All 
Night. Elite (English And Litelature Journal), 10(2), 1-15.

Harya, T. D. (2017). An Analysis Of Figurative Languages Used In Coelhos's Novel Entitled "Alchemist." Premise Journal:Issn Online: 2442-482x, Issn Printed: 2089-3345, 5(2), 46.

Kaswan, Dasep Suprijadi, L. S. (2016). Research In English Language Education (Revisied Edition). Ikip (Institut Kenguruan Dan Ilmu Pendidikan) Bandung.

Nurcitrawati, V., Kareviati, E., \& Atmawidjaja, N. (2019). Figurative Language Analysis In Disney Songs. Project (Professional Journal Of English Education), 2(4), 494.

Nurdiansyah, D. M. R., Asyid, S. A., \& Parmawati, A. (2019). Using Color Coding To Improve Students'english Vocabulary Ability. Project (Professional Journal Of English Education), 2(3), 358-363.

Nurhaida, \& Marlina, L. (2017). An Analysis Of Figurative Language In Views (Opinion Column) Of Online Padang Ekspres Newspaper. E-Journal Of English Language \& Literature, 6(2).

Padillah, E. N., Firmawan, H., \& Purwaningsih, E. (2016). Simile, Hyperbole, Personification And Metaphor Used In Gayle Forman's If I Stay. Jurnal Ilmiah Sastra, 4(1), 69-78.

Seixas, B. V., Smith, N., \& Mitton, C. (2018). The Qualitative Descriptive Approach In International Comparative Studies: Using Online Qualitative Surveys. International Journal Of Health Policy And Management, 7(9), 778-781.

Setiawati, W., \& Maryani, M. (2018). An Analysis Of Figurative Language In Taylor Swift's Song Lyrics. Project (Professional Journal Of English Education), 1(3), 261.

Zayn \& Zhavia Ward - A Whole New World (End Title) Lyrics | Genius Lyrics. (N.D.). 